\title{
CREATION OF PHARMACEUTICAL COMPOSITIONS WITH THE ANTIFUNGAL, ANTIMICROBIAL AND KERATOLYTIC ACTIVITY
}

\author{
O.I.Tikhonov, O.E.Frolova*, O.S.Shpychak
}

National University of Pharmacy

SI "Lugansk State Medical University” of the Ministry of Health of Ukraine, Rubizhne*

Key words: propolis; "Propolis-Derma" pharmaceutical compositions; antifungal, antimicrobial and
keratolytic action

The microbiological studies of "Propolis-Derma" medicated products ("Propolis-PNH", "Propolis-PSC" and "Propolis-PCD") with the antifungal, antimicrobial and keratolytic activity developed for the treatment of dermatomycoses, pityriasis versicolor, as well as diseases caused by yeast-like fungi of Candida genus have been carried out. The results of the experiments conducted indicate that the test samples studied show marked antagonistic properties against gram-positive bacteria (S. aureus, B. subtilis), the selective antibacterial ability in relation to E. Coli and the expressed antifungal action against the strains of Candida albicans genus. It has been determined that the pharmaceutical compositions proposed do not reveal the adverse action and comply with the requirements of the State Pharmacopeia of Ukraine. They can be used to treat mycoses in conditions of high resistance of fungi to traditional antifungal drugs.

$\mathrm{U}$ nder present-day conditions pathogens of fungal diseases or dermatomycoses are pathogenic fungi parasitizing on the human skin and mucous membranes [2, 3]. Data from current literature sources indicate that their amount has considerably increased in recent years, therefore, dermatologists rather often have to diagnose pathologies with dermatophytes, yeast-like fungi of Candida genus, molds and dimorphic fungi, etc. [1]. According to the WHO data every fifth inhabitant of our planet is prone to affection of fungal infection [17]. Among mycoses of various degree, the fungal diseases of the feet (athlete's foot) and nail disorders (onychomycoses) are the most often. Usually the source of spreading the infection is the sick persons; however, some fungal infections are natural part of the microflora of a healthy person.

For development of affections of the skin and nails certain conditions are necessary, they include weakening of both general and local immunity, diseases of the endocrine system, dysfunction of the skin that is a barrier between external and internal environment of the body, excessive sweating, etc. [14].

First symptoms of the fungal lesion are itching, discolouration, appearance of inflammations and the skin flaking on the affected areas. However, the main danger is not discomfort, but the waste products of fungi that exhibit toxic effects on the patient's organism $[2,8,14]$. Over time it can lead to deformation of the skin, bacterial and viral complications, therefore, treatment of skin fungal diseases should be as soon as possible when the first signs appear.

When choosing the pharmacotherapy of fungal infections the preference should be given to substances and drugs that exhibit a wide range of the therapeutic activity In this respect, the products of beekeeping and their combinations with biologically active substances of natural and synthetic origin, namely the tincture of propolis, dimethylsulphoxide, econazole nitrate, chlorhexidine digluconate, naftifine hydrochloride, the propolis phenolic hydrophobic drug

O.I.Tikhonov - Doctor of Pharmacy, Honoured Professor of the Department of Cosmetology and Aromalogy of the National University of Pharmacy (Kharkiv)

O.Ye.Frolova - a post-graduate student of the Department of Technology of Drugs, SI "Lugansk State Medical University" of the Ministry of Health of Ukraine (Rubizhne)

(PPHD), the aqueous extract of propolis, etc., are of particular importance, in our opinion [18].

As aforesaid, the search for new effective antifungal drugs is also one of the pressing problems of practical healthcare.

The pharmaceutical compositions under the conditional name "Propolis-Derma" ("Propolis-PNH", "Propolis-PSC" and "Propolis-PCD") have been developed for the treatment of dermatomycoses, pityriasis versicolor, as well as diseases caused by yeast-like fungi of Candida genus $[4,5]$. According to the data of pharmacological tests the active pharmaceutical ingredients in the composition of water-alcohol solutions of "Propolis-Derma" act on the process of sterol biosynthesis and reduce the activity of squalene epoxidase enzyme in cellular membranes of fungi, resulting in their death. "PropolisPNH", "Propolis-PSC" and "Propolis-PCD" drugs show the fungicidal and fungistatic action in relation to yeast fungi and the fungicidal action in relation to dermatophytes, molds and dimorphic fungi; they are recommended for use in mycosis of the scalp, skin candidiasis, dermatomycosis of the trunk and extremities.

It is known from the literary sources that modern antifungal 
Table 1 clinical strains of Candida fungi

\section{The composition of "Propolis-Derma" pharmaceutical compositions with the antifungal, antimicrobial and keratolytic action}

\begin{tabular}{|c|l|c|}
\hline $\begin{array}{c}\text { No., the name } \\
\text { of the sample }\end{array}$ & \multicolumn{1}{|c|}{$\begin{array}{c}\text { Composition of the sample } \\
\text { 1. "Propolis-PNH" }\end{array}$} & $\begin{array}{l}\text { Naftifine hydrochloride } \\
\text { Tincture of propolis }\end{array}$ \\
\hline \multirow{3}{*}{ 2. "Propolis-PSC" } & Chlorquinaldol & 0.1 \\
& Tincture of propolis & 2.0 \\
& Salicylic acid & 77.2 \\
\hline \multirow{3}{*}{ 3. "Propolis-PCD" } & C6\% ethanol & 0.8 \\
& Tincture of propolis & 20.0 \\
\hline & 96\% ethanol & 8.0 \\
\hline
\end{tabular}

agents should be presented in several dosage forms, each of which with certain advantages, it allows to satisfy the needs of different groups of patients providing them the minimum dosage frequency for convenience [9]. In fungal affections accompanied with the increased skin dryness and cracking it is recommended to apply the cream. On the contrary, if a patient complains about itching and appearance of moist areas on the skin, it is worth to offer a dermatological gel. To treat hair (microsporia), body folds (candidiasis) or significant skin areas (pityriasis versicolor) it is recommended to use a spray, which can be also useful for footwear or underwear, in particular socks, and it will be able to improve efficacy of treating fungal pathologies.

The availability of different dosage forms provides a comfortable therapy for any form of fungal skin lesions. It should be noted that frequency of application and duration of therapy with "Propolis-Derma" medicated products depend on the nature and severity of the pathological process.

\section{Materials and Methods}

The aim of this work is to develop "Propolis-Derma" pharmaceutical compositions with the antifungal, antimicrobial and keratolytic activity. Due to the optimal ratio active substances and exci- pients they can exhibit a high therapeutic effect in mixed infectious diseases of the skin and provide a wider range of the fungicidal and antimicrobial action. The compositions under research are "Propolis-PNH", "Propolis-PSC" and "Propolis-PCD", and they contain: 1) the tincture of propolis and naftifine hydrochloride; 2) tincture of propolis, chlorquinaldol, salicylic acid and ethanol; 3) the tincture of propolis, chlorhexidine hydrochloride and ethanol $[5,6,7]$. The compositions of the experimental samples of drugs are presented in Table 1.

The pharmaceutical compositions developed (Tab. 1) were subjected to microbiological activity tests conducted at the State Institution "Institute of Microbiology and Immunology named after I.I.Mechnikov of the National Academy of Medical Sciences of Ukraine" under the supervision of the head of the Laboratory of Biochemistry of Microorganisms and Nutrient Media, Candidate of Biology, senior researcher T.P.Osolodchenko.

The antimicrobial activity of the experimental samples of "Propolis-Derma" was determined by the agar (well) diffusion method. A set of reference strains of such microorganisms as $S$. aureus ATSS 6538, E. coli ATSS 8739, P. aeruginosa ATSS 9027, B. subtilis ATSS 6633, C. albicans ATSS 10231 and were used in the study. The general plan of the research was as follows: tests were carried out by the method based on the ability of medicinal substances to penetrate into agar.

Petri dishes were filled with two layers of the solid medium. The lower layer was $10 \mathrm{ml}$ of the melted starvation agar (medium 3), the upper layer was the nutrient medium for the corresponding test strain. After cooling of the lower layer of agar three steel thin-walled cylinders (the internal diameter $-6.0 \pm 0.1 \mathrm{~mm}$, the height $10.0 \pm 0.1 \mathrm{~mm}$ ) were placed at an equal distance from each other and from the edge of the dish. Around the cylinders the upper layer was filled with $13.5 \mathrm{ml}$ of the melted agar cooled to $45-48^{\circ} \mathrm{C}$, mixed with the inoculation dose of a test microorganism $1.5 \mathrm{ml}$ of the microbial suspension with the concentration corresponding to the type of a microorganism). After cooling of the upper layer of agar the cylinders were removed by a sterile forceps, and 0.25 $0.3 \mathrm{ml}$ of the drug studied was placed in the wells.

Processing of the results was conducted in 24 hours by measuring the inhibition zone, including the diameter of wells. Measurements were performed with the accuracy up to $1 \mathrm{~mm}$ taking into account the complete absence of visible growth.

The results obtained were assessed by the following criteria:

- a $6 \mathrm{~mm}$ diameter area was assessed as the absence of the antimicrobial effect;

- a 7-14 mm diameter area as a negligible antimicrobial effect;

- a 15-19 mm diameter area as a moderate antimicrobial effect;

- a $20 \mathrm{~mm}$ and more - as a high antimicrobial effect.

The data obtained were analysed by the methods of variation statistics. The acceptable significance level is $\mathrm{p}<0.05$. 
Table 2

The results of growth inhibition of microorganisms in "Propolis-Derma" drugs under study

\begin{tabular}{|l|c|c|c|c|c|}
\hline \multirow{2}{*}{ Name of the sample } & \multicolumn{5}{|c|}{ The inhibition zone, $\mathrm{mm}$} \\
\cline { 2 - 6 } & S. aureus & E. coli & B. subtilis & P. aeruginosa & C. albicans \\
\hline Sample 1 "Propolis-PNH" & 25 & 20 & 30 & $*$ & $*$ \\
\hline Sample 2"Propolis-PSC" & 25 & 25 & 30 & $*$ & $*$ \\
\hline Sample 3 "Propolis-PCD" & 25 & 25 & 30 & $*$ & $*$ \\
\hline
\end{tabular}

Note:"-" - the inhibition zone is absent; "*" - samples require repeated studies.

\section{Results and Discussion}

The results of the antimicrobial activity screening (Tab. 2) indicate the ability of the test samples studied inhibit the growth of microorganisms. The results of this work show that these test samples exhibit marked antagonistic properties against gram-positive bacteria (S. aureus, B. subtilis) and the selective antibacterial ability in relation to $E$. coli.

Considering the expressed activity in relation to fungi of Candida genus it was expedient to focus on determining the antifungal abilities of the samples of the drugs under study. In our experiments the reference culture of C. albicans and some cultures of Candida genus fungi isolated in a clinical setting were used. The fungi of Candida albicans genus freshly isolated showed the whole complex of signs inherent to this type of fungi. The results of the experiment are presented in Table 3.

The results of the screening in determining the sensitivity of Candida albicans genus fungi to the samples of "Propolis-Derma" pharmaceutical compositions showed that the reference culture and clinical strains of Candida albicans genus fungi were the most sensi- tive to test samples 1 "PropolisPNH" and 2 "Propolis-PSC" (the inhibition zone ranged within 40 $55 \mathrm{~mm}$ ). One should also note the high sensitivity of clinical strains to these drugs compared with the reference culture and the presence of a high fungicidal activity in samples 1 and 2 and a moderate activity in sample 3 "Propolis-PCD".

Considering analysis of the literature sources and the results of our own microbiological studies of "Propolis-Derma" pharmaceutical compositions it should be noted that it is expedient to use these active substances, in particular the tincture of propolis, chlorhexidine digluconate, chlorquinaldol, salicylic acid and naftifine hydrochloride, when developing new domestic medicated products for dermatological practice.

According to the literature data and the research results the tincture of propolis contains approximately seven natural antibiotics to which microorganisms do not adapt and about fifty biologically active substances that lead to a wide spectrum of the pharmacological action [18]. The drug is also applied to treat the pathological conditions caused by bacteria [18]. Due to its antifungal properties it can be successfully used in yeast, candidal vaginal infection caused by fungi and in the case of common fungal infections - on hands, legs and nails $[11,13,15]$. The analgesic, emollient and plastic action of propolis allowed to use it as a base for keratolytic ointments in combinations with other drugs, particularly salicylic acid. The alcoholic tincture of propolis shows antiseptic (antibacterial, antiviral and antifungal), wound-healing, analgesic, antipruritic, antitoxic and antioxidant properties, decreases blood clotting, reduces the vascular spasm, stimulates metabolic and protective reactions of the body [18].

Chlorquinaldol is used in inflammatory diseases of the mouth, stomatitis, fungal affection of the oral cavity, colpitis and vulvovaginitis of the fungal and bacterial etiology, dysentery, salmonellosis, bacterial food poisoning, dysbacteriosis. However, this substance does not solve the problem in case of mycoses complicated by hyperkeratosis, but effectively prevents the secondary fungal infections [16].

Salicylic acid is widely used in organic synthesis and functions as a plant hormone. It is a derivative of metabolism of salicyl -

Table 3

The indicators of the antifungal action of "Propolis-Derma" drugs

\begin{tabular}{|l|c|c|c|c|}
\hline \multirow{2}{*}{ Name of the sample } & \multicolumn{4}{|c|}{ The inhibition zone, mm } \\
\cline { 2 - 5 } & C. albicans & Clinical strain 1529 & Clinial strain 1434 & Clinical strain 1671 \\
\hline Sample 1 "Propolis-PNH" & 52 & 40 & 45 & 45 \\
\hline Sample 2"Propolis-PSC" & 50 & 53 & 55 & 50 \\
\hline Sample 3"Propolis-PCD" & 32 & 40 & 30 & 28 \\
\hline
\end{tabular}


the most popular drug in the treatment of acne $[10,18]$.

Chlorhexidine hydrochloride is an antiseptic, which is used in the form of digluconate in the finished dosage forms. Chlorhexidine has been successfully used as a skin antiseptic and disinfectant for over 60 years [10].

Naftifine hydrochloride is an antifungal agent for external application, which belongs to the class of allylamines. It provides a high activity against various fungi (dermatophites, molds and yeastlike fungi in vitro), exhibits mainly the fungicidal effect on dermatophites and molds, as well as fungistatic or fungicidal properties on yeast-like fungi depending on their strain.

With regard to the mechanism of action of most antifungal drugs, it is associated with interaction of the key enzymes affecting the process of the biosynthesis of ergosterol, which is part of fungal cell membranes at the major stages: acetyl - coenzyme A - squalene - lanosterol - ergosterol [9]. Moreover, the fungicidal action of allylamines is associated with disturbance of stage 3 of the ergosterol biosynthesis by inactivation of squalene epoxidase enzyme. It leads to deficiency of ergosterol in the cellular membrane and accumulation of squalene, which is a toxic substance that causes death of the fungal cell [12].

Drugs of this group do not affect the cytochrome $\mathrm{P}_{450}$ system and the synthesis of human ste- roid structures carrying out with involvement of cytochrome $\mathrm{P}_{450^{-}}$ dependent enzyme - 14 alpha-demethylase. Considering the fact that most drugs are metabolized by the cytochrome $\mathrm{P}_{450}$ system naftifine hydrochloride can be prescribed in mycoses of different etiology to the elderly people with comorbidities requiring administration of other medicines [4].

In addition, it was found, for example, that the action of naftifine hydrochloride depends on the $\mathrm{pH}$ value; the highest activity of the drug is observed in the range of the neutral pH values. Naftifine hydrochloride inhibits squalene epoxidase, suppressing the biosynthesis of ergosterol - the essential component of fungal cell membranes. As a result, deficiency of ergosterol and the growth of the fungal cells stop.

Hence, the fungistatic action of naftifine hydrochloride is explained by insufficient production of ergosterol hormone. On the other hand, accumulation of squalenes associated with inhibition of squalene epoxidase leads to certain degenerative intracellular processes, for instance, deposition of lipid droplets. This accumulation of squalene is not only in cellular membranes, but also in other membranes. Disturbance of properties of membranes and all intercellular processes associated with lipid membranes can cause the cell wall damage, and it explains the fungicidal action of naftifine hydrochloride.
Thus, the tests indicate a marked antifungal effect of "PropolisDerma" medicated products against strains of Candida albicans genus fungi. Moreover, the samples 1 and 2 should be considered to be the most promising for further study. The clinical trials conducted have shown that the combinations proposed do not have side effects, except for individual intolerance of ingredients included in the composition of the samples under study.

\section{CONCLUSIONS}

1. "Propolis-Derma" medicated products with the antifungal, antimicrobial and keratolytic activity containing the tincture of propolis and such active pharmaceutical ingredients as naftifine hydrochloride or chlorquinaldol, salicylic acid and ethanol, or chlorhexidine hydrochloride and ethanol have been developed.

2 . The results of microbiological studies of the pharmaceutical compositions proposed indicate that the test samples studied show marked antagonistic properties against gram-positive bacteria ( $S$. aureus, B. subtilis), the selective antibacterial ability in relation to E. Coli and the antifungal action against the strains of Candida albicans genus.

3. The samples of drugs "Propolis-PNH”, "Propolis-PSC”, "Propolis-PCD" under study meet the requirements of the SPhU and can be used to treat mycoses in conditions of high resistance of fungi to traditional antifungal drugs.

\section{REFERENCES}

1. Абдалкин М.Е. // Электронный науч. журн. «Современные проблемы науки и образования». 2011. - №4.

2. Багирова Н.С. // Злокачественные опухоли. - 2013. - №2 (6). - С. 3-11.

3. Белоусова Т.А., Горячкина М.В. // Рус. мед. журн. (Дерматол.) - 2011. - Т. 19, №11. - С. 688-692.

4. Ващенко О.О., Калинюк Т.Г., Зайченко О.І. // Клінічна фармація. - 2009. - Т. 13, №4. - С. 17-21.

5. Висновок державної санітарно-епідеміологічної експертизи від 30.06.2016 № 05.03.02-07/22191. Рещептури на лосьйони косметичні: «Прополіс - ПСХ» РЦ № 3320715444-01:2016; «Прополіс - ПХД» РЦ № 3320715444-02:2016; «Прополіс - ПНГ» РЦ № 3320715444-03:2016 відповідно до ДСТУ 4093-2002 «Лосьйони та тоніки косметичні. Технічні умови». - К.: Державна санітарноепідеміологічна служба, 2016. - 1 с. 
6. Висновок державної санітарно-епідеміологічної експертизи від 30.06.2016 № 05.03.02-04/22198. Лосьйони косметичні: «Прополіс - ПСХ», «Прополіс - ПХД», «Прополіс - ПНГ» відповідно до ДСТУ 4093-2002 «Лосьйони та тоніки косметичні. Технічні умови». - К.: Державна санітарноепідеміологічна служба, 2016. - 2 с.

7. ДСТУ 4093-2002 «Лосьйони та тоніки косметичні». Технічні умови. Видання офіційне. - К.: Держстандарт України, 2002. - 8 с.

8. Закирова А.А., Файзуллина Е.В. // Современная медицина: актуальные вопросы. - 2014. - №30. - C. 3-9.

9. Климко Н.Н. Микози: диагностика и лечение: Руководство для врачей. - М.: Премьер МТ, 2007. -336 c.

10. Косинец А.Н., Фролова А.В., Булавкин В.П., Окулич В.К. // Вестник ВГМУ. - 2014. - Т. 13, №2. C. $70-77$.

11. Мельникова Н.В. Розробка складу, технології та дослідження м'яких лікарських засобів антимікотичної дії з олією чебрецю: автореф. дис. ... канд. мед. наук / Н.В.Мельникова. - Запоріжжя, 2015. -24 c.

12. Сергеев А.Ю., Сергеев Ю.В. Грибкововые инфекции: Руководство для врачей. - 2-е изд. - М.: «Бином - пресс», 2008. - 440 с.

13. Тихонов О.І., Фролова О.Є., Гудзенко О.П., Барнатович С.В. // Соціальна фармація в охороні здоров'я. - 2016. - Т. 2, №2. - С. 77-81.

14. Файзуллина Е.В. Онихомикозы: эпидемиология, факторы риска, пути оптимизации медицинской помощи. - Казань: «Медицина», 2010. - 204 с.

15. Чорна Н.А. Розробка складу та технології гомеопатичної мазі для застосування в дерматології: Автореф. дис. ... канд. фарм. наук. - Х., 2009. - 23 с.

16. Bulkina N.V., Panchenko A.D. // Saratov J. of Med. Sci. Res. - 2011. - Vol. 7, №1 (Suppl.). - P. 319-321.

17. The WHO policy package to combat antimicrobial resistance // Bulletin of the World Health Organization. - 2011. - №89. - P. 390-392.

18. Tikhonov A.I., Iarnykh T.G., Chernych V.P., Zupanets I.A., Tikhonova S.A. Teoria i praktyka wytwarzania leczniczych preparatow propolisowych // Pod redakcja akademika A.I. Tichonowa Redaktor wydania polskiego prof. dr hab. Bogdan Kedzia. - Krakow: Drukaznia "Marka", 2005. - 274 p.

\title{
СТВОРЕННЯ ФАРМАЦЕВТИЧНИХ КОМПОЗИЦІЙ АНТИГРИБКОВОЇ, АНТИМІКРОБНОЇ І КЕРАТОЛІТИЧНОЇ АКТИВНОСТІ
}

О.І.Тихонов, О.є.Фролова*, о.С.Шиичак

Національний фармацевтичний університет, Державний заклад «Луганський державний медичний університет» МОЗ України, м. Рубіжне*

Ключові слова: прополіс; фармацевтичні композицї̈ «Прополіс-Дерма»;

протигрибкова дія; антимікробна дія; кератолітична дія

\begin{abstract}
Проведені мікробіологічні дослідження лікувально-профілактичних засобів «Прополіс-Дерма» («Прополіс-ПнГ», «Прополіс-ПСХ» та «Прополіс-ПХД») з протигрибковою, антимікробною і кератолітичною активністю, створених для лікування дерматомікозів, різнобарвного лишаю, а також захворювань, спричинених дріжджоподібними грибами роду Candida. Результати проведених випробувань свідчать, що досліджувані тест-зразки проявляють виражені антагоністичні властивості по відношенню до грампозитивних бактерій (S. aureus, B. subtilis) та вибіркову антибактеріальну здатність до E. coli, а також виражену антифунгальну дію відносно штамів грибів роду Candida albicans. Встановлено, що запропоновані фармацевтичні композиції не проявляють побічної дії та відповідають вимогам Державної фармакопеї України і можуть бути використані для лікування мікозів в умовах високої резистентності грибків до традиційних протигрибкових лікарських засобів.
\end{abstract}




\section{СОЗДАНИЕ ФАРМАЦЕВТИЧЕСКИХ КОМПОЗИЦИЙ ПРОТИВОГРИБКОВОЙ, ПРОТИВОМИКРОБНОЙ И КЕРАТОЛИТИЧЕСКОЙ АКТИВНОСТИ}

А.И.Тихонов, О.Е.Фролова*, О.С.Шпичак

Национальный фармацевтический университет, Государственное заведение «Луганский государственный медицинский университет» МЗ Украины, г. Рубежное

Ключевые слова: прополис; фармацевтические композиции «Прополис-Дерма»; противогрибковое, противомикробное и кератолитическое действие

Проведены микробиологические исследования лечебно-профилактических средств «Прополис-Дерма» («ПрополисПНГ», «Прополис-ПСХ» и «Прополис-ПХД») с противогрибковой, противомикробной и кератолитической активностью, созданных для лечения дерматомикозов, разноцветного лишая, а также заболеваний, вызванных дрожжеподобными грибами рода Candida. Результаты проведенных испытаний показывают, что исследуемые тест-образцы проявляют выраженные антагонистические свойства в отношении грамположительных бактерий (S. aureus, B. subtilis) и выборочную антибактериальную способность к E. coli, а также выраженное антифунгальное действие в отношении штаммов грибов рода Candida albicans. Установлено, что предложенные фармацевтические композиции не проявляют побочного действия и отвечают требованиям Государственной фармакопеи Украины и могут быть использованы для лечения микозов в условиях высокой резистентности грибков к традиционным противогрибковым лекарственным средствам.

Address for correspondence:

Received in 28.07.2016

4, Valentynivska str., Kharkiv, 61168, Ukraine.

Tel. (50) 400-75-82. E-mail: shpichak_oleg@ukr.net.

National University of Pharmacy 